\title{
ASSESSMENT OF PHYSICOCHEMICAL AND BACTERIOLOGICAL PARAMETERS IN THE SURFACE WATER OF THE JUAN DIAZ RIVER, PANAMA
}

\author{
QUIRIATJARYN M. ORTEGA-SAMANIEGO ${ }^{1,2}$, INMACULADA ROMERO $^{1}$, MARÍA PACHES $^{1}$, \\ ARTURO DOMINICI ${ }^{3} \&$ ANDRES FRAÍZ ${ }^{4}$ \\ ${ }^{1}$ Research Institute of Water and Environmental Engineering, Universitat Politècnica de València, Spain \\ ${ }^{2}$ Ministerio de Ambiente de Panamá, Panamá \\ ${ }^{3}$ Universidad Marítima Internacional de Panamá, Panamá \\ ${ }^{4}$ Wetlands International, Panama City, Panamá
}

\begin{abstract}
Water pollution represents an obstacle to the development of countries since it affects not only the social-economic component but also biodiversity. Little is documented on the state of water quality of the rivers that flow through Panama City, so it is important to be able to determine the degree of contamination whether of natural or anthropogenic origin, in order to take actions that seek to remediate and increase the resilience of wetland ecosystems. For this study, a database of the Ministry of the Environment of Panama of water quality monitoring during the years 2002-2018 from the Juan Díaz River in the Republic of Panama was used. With these data, a space-temporal analysis was carried out to determine significant differences between the study sites using the Kruskal-Wallis Test and between seasons (dry and wet) by means of the Mann-Whitney U Test, and evaluation of the water quality index (WQI). The results indicate that there are significant differences between sites for the parameters of $\mathrm{pH}, \mathrm{T}\left({ }^{\circ} \mathrm{C}\right)$, conductivity $(\mathrm{mS} / \mathrm{m})$, turbidity $(\mathrm{NTU}), \mathrm{DO}(\mathrm{mg} / \mathrm{L}), \mathrm{BOD}_{5}(\mathrm{mg} / \mathrm{L}), \mathrm{TS}(\mathrm{mg} / \mathrm{L}), \mathrm{SS}(\mathrm{mg} / \mathrm{L})$, $\mathrm{DS}(\mathrm{mg} / \mathrm{L}), \mathrm{NO}_{3}(\mathrm{mg} / \mathrm{L}), \mathrm{PO}_{4}(\mathrm{mg} / \mathrm{L})$, fecal coliforms (CFU/100 mL), T. coliforms (CFU/100 mL) and there are no significant differences between seasons except for the $\mathrm{PO}_{4}$ parameter. Analysing the WQI values, all the stations sampled are in the ranges from 17 (highly polluted) to 88 (acceptable).

Keywords: physicochemical parameters, bacteriological parameters, WQI (water quality index), spatio-temporal analysis, Juan Diaz river, Panama.
\end{abstract}

\section{INTRODUCTION}

The deterioration of surface water bodies means a great crisis for human development [1]. Therefore, it is essential to investigate the causes and effects on the environment since we depend on this resource for domestic and economic activities [2]. Tools are required to detect the influence of pollutants early and indicate the level of impact [3]. The spatio-temporal analyzes of the physicochemical parameters of the water allow to study the short and long changes of alterations in the nature of the water body [4].

According to the Water Quality Monitoring Report in the Hydrographic Basins of Panama Compendium of Results Years 2002-2008 for the study of the basin, the following anthropogenic pressures were detected: water extraction, poor management of agricultural and livestock production, inappropriate use of soils, urban development near drainage areas, sedimentation resulting from deforestation, floods, contamination by solid waste and industrial pollutants [5]. High concentrations of pollutants and eutrophication processes can cause loss of biodiversity in addition to affecting the quality of life of communities. Therefore, the social, political, and economic component must be considered to reduce and eliminate the environmental impacts in the Juan Diaz River basin.

A spatio-temporal evaluation of physical, chemical, biological parameters and WQI (water quality index) was carried out in order to observe significant differences between study sites and seasons. 


\section{MATERIALS AND METHODS}

\subsection{Study area}

The Juan Díaz River is located in the urban area of Panama City specifically in the eastern Pacific of the country [5], being for the most part geographically rugged because it is the last site where the Isthmus of Panama was formed approximately 20 million a year [6]. It is bordered to the north by the Canal Basin 115, to the south by the coastal zone of the Bay of Panama, to the east by the Pacora River basin 146 and to the west by Basin 142 whose main river is the Matasnillo [5]. Within this basin are the district of Panama and San Miguelito, seven townships (Las Cumbres, Tocumen, Belisario Porras, Jose D. Espina, Juan Diaz, Pedregal, and Mateo Iturralde) [7]. Sampling points are shown in Fig. 1.

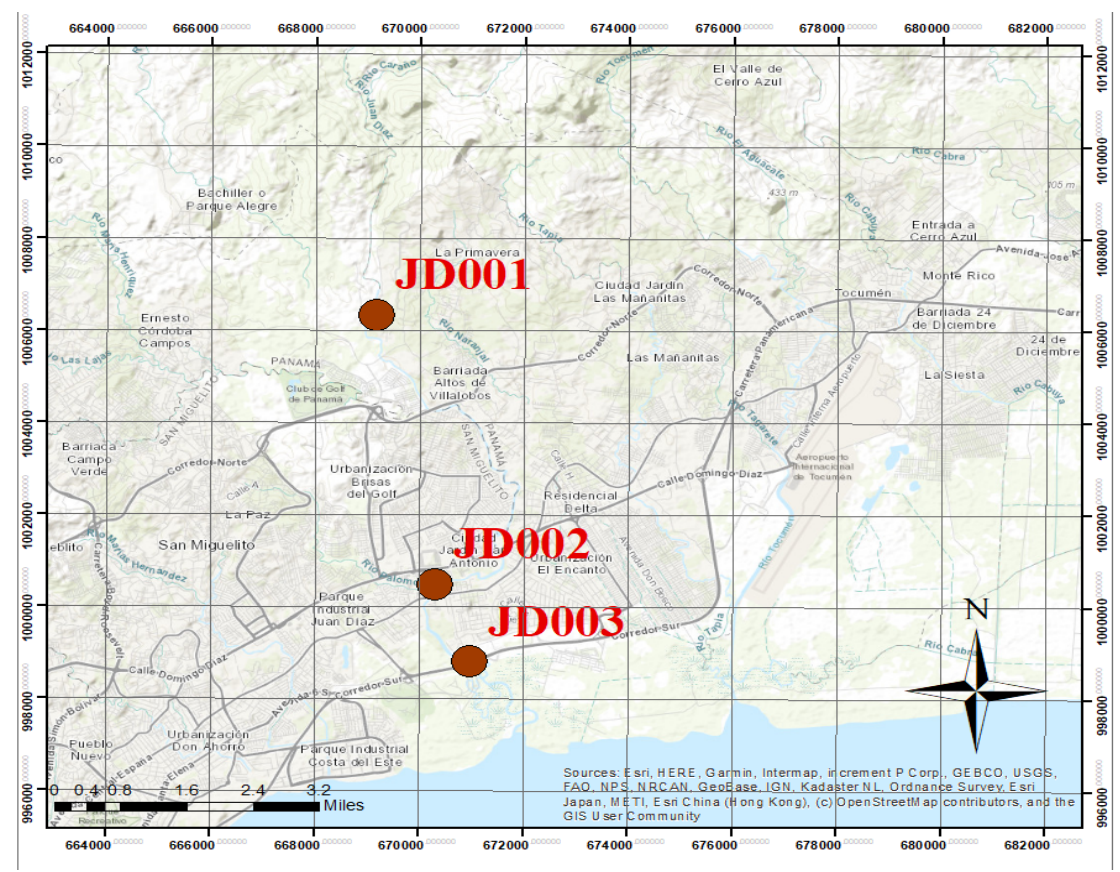

Figure 1: Location of the study sites.

\subsection{Analysis of physicochemical and bacteriological parameters}

The parameters used in this paper were $\mathrm{pH}$, temperature: $\mathrm{T}\left({ }^{\circ} \mathrm{C}\right)$, conductivity $(\mathrm{mS} / \mathrm{m})$, turbidity (NTU), dissolved oxygen: OD mg/L), biochemical oxygen demand: BOD $_{5}(\mathrm{mg} / \mathrm{L})$, total solids: TS (mg/L), suspend solids: SS (mg/L), dissolved solids: DS (mg/L), nitrates: $\mathrm{NO}_{3}(\mathrm{mg} / \mathrm{L})$, phosphates: $\mathrm{PO}_{4}(\mathrm{mg} / \mathrm{L})$, fecal coliforms $(\mathrm{CFU} / 100 \mathrm{~mL})$, total coliforms $(\mathrm{CFU} / 100 \mathrm{~mL})$. The data were collected and characterized in the laboratory by technicians from the Ministry of the Environment of Panama following the guidelines of the Standard Methods [8], during the dry and wet season between the years 2002 to 2018 as can be seen in Table 1, the sampling study sites were JD001 (Villalobos Bathing Site), JD002 (Los Pueblos Mall and) JD003 (South Bridge Corridor). 


\begin{tabular}{|c|c|c|c|c|c|c|c|c|c|c|c|c|c|c|}
\hline 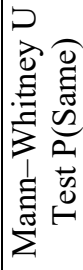 & 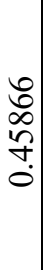 & $\begin{array}{l}0 \\
= \\
\exists \\
= \\
0\end{array}$ & $\begin{array}{l}\vec{D} \\
\infty \\
\stackrel{D}{n} \\
\dot{0}\end{array}$ & $\begin{array}{c}\hat{N} \\
\hat{0} \\
\tilde{n} \\
0 \\
0\end{array}$ & $\begin{array}{l}0 \\
\infty \\
\hat{n} \\
0\end{array}$ & $\begin{array}{l}\bar{\sigma} \\
\overline{0} \\
\tilde{2} \\
0 \\
0\end{array}$ & $\begin{array}{l}n \\
n \\
n \\
\infty \\
0 \\
0 \\
0\end{array}$ & 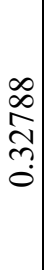 & $\frac{0}{\tilde{n}}$ & $\begin{array}{l}\stackrel{a}{g} \\
\dot{J} \\
\tilde{m} \\
0\end{array}$ & $\begin{array}{l}n \\
m \\
\tilde{\omega} \\
\infty \\
0 \\
0 \\
0\end{array}$ & 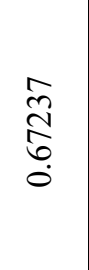 & 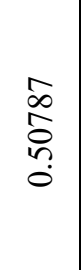 & . \\
\hline 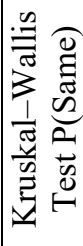 & \begin{tabular}{|l}
$n$ \\
2 \\
0 \\
0 \\
0 \\
0 \\
0
\end{tabular} & $\begin{array}{l}\text { o } \\
0 \\
\\
8 \\
0 \\
0 \\
0\end{array}$ & 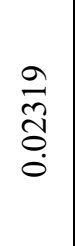 & $\begin{array}{l}0 \\
\stackrel{n}{0} \\
8 \\
8 \\
8 \\
8 \\
8 \\
0 \\
0\end{array}$ & $\begin{array}{l}0 \\
0 \\
1 \\
\infty \\
\infty \\
0 \\
i\end{array}$ & 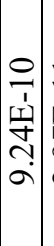 & $\begin{array}{l}= \\
\overline{1} \\
\dot{1} \\
\hat{\sigma} \\
i\end{array}$ & 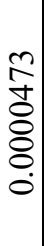 & 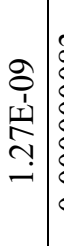 & $\begin{array}{l}\text { م. } \\
0 \\
8 \\
8 \\
8 \\
8 \\
8 \\
0 \\
0\end{array}$ & $\begin{array}{l}\text { ․ } \\
\overline{8} \\
8 \\
8 \\
8 \\
0 \\
0\end{array}$ & $\begin{array}{l}\stackrel{\infty}{0} \\
\stackrel{1}{1} \\
\stackrel{1}{\infty} \\
\infty \\
\infty \\
\infty\end{array}$ & $\underset{\substack{n \\
\text { n. }}}{\stackrel{0}{1}}$ & 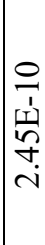 \\
\hline 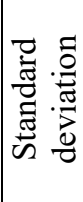 & $\begin{array}{l}\infty \\
m \\
0\end{array}$ & 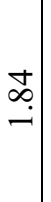 & $\begin{array}{l}\text { oे } \\
\dot{5} \\
\text { ते }\end{array}$ & $\begin{array}{l}\mathscr{n} \\
\dot{\sigma} \\
\stackrel{\sim}{\forall}\end{array}$ & $\begin{array}{l}\stackrel{g}{t} \\
\dot{v}\end{array}$ & \begin{tabular}{|l} 
\\
0 \\
$i$ \\
$n$
\end{tabular} & $\begin{array}{l}\text { D. } \\
\dot{\infty} \\
-\end{array}$ & $\begin{array}{l}n \\
n \\
\infty \\
0 \\
0\end{array}$ & $\begin{array}{c}\tilde{g} \\
\dot{\Xi}\end{array}$ & $\begin{array}{l}0 \\
\stackrel{n}{n} \\
m\end{array}$ & $\begin{array}{l}0 \\
\stackrel{0}{+} \\
-\end{array}$ & 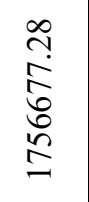 & 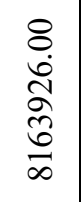 & 㐫. \\
\hline 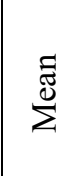 & $\stackrel{n}{n}$ & $\overrightarrow{\widetilde{N}}$ & 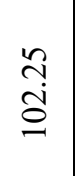 & 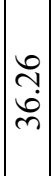 & $\begin{array}{l}\mathfrak{6} \\
\dot{\tau}\end{array}$ & $\left|\begin{array}{c}\sigma \\
\vdots \\
\sim \\
v\end{array}\right|$ & 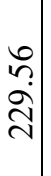 & $\begin{array}{c}a \\
\dot{v} \\
i \\
n\end{array}$ & $\begin{array}{l}\bar{a} \\
\tilde{b} \\
-1\end{array}$ & $\begin{array}{c}n \\
\infty \\
\dot{r}\end{array}$ & $\tilde{n}$ & 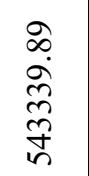 & $\begin{array}{l}\text { ஸे } \\
\stackrel{1}{1} \\
\stackrel{\infty}{\infty} \\
\stackrel{-}{\sigma}\end{array}$ & $\frac{\infty}{n}$ \\
\hline 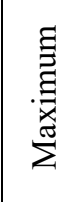 & $\begin{array}{c}q \\
+ \\
\infty\end{array}$ & 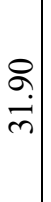 & $\begin{array}{l}\stackrel{8}{8} \\
\stackrel{2}{2} \\
\stackrel{2}{n}\end{array}$ & $\mid \begin{array}{l}0 \\
n \\
0 \\
\stackrel{0}{7}\end{array}$ & 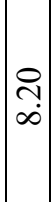 & $\begin{array}{c}8 \\
0 \\
\infty \\
\dot{1} \\
m\end{array}$ & $\begin{array}{l}8 \\
0 \\
\dot{0} \\
\\
=\end{array}$ & $\begin{array}{l}8 \\
\vdots \\
\grave{1} \\
\infty\end{array}$ & $\begin{array}{l}\vec{n} \\
\tilde{8} \\
\underline{Z}\end{array}$ & $\begin{array}{l}\stackrel{8}{0} \\
\stackrel{0}{-} \\
-\end{array}$ & $\begin{array}{l}\stackrel{ \pm}{\sim} \\
\stackrel{5}{ }\end{array}$ & $\begin{array}{l}8 \\
8 \\
8 \\
8 \\
8 \\
\infty \\
\infty\end{array}$ & 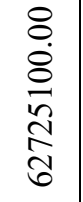 & $\infty$ \\
\hline 志 & $\stackrel{?}{\stackrel{0}{6}}$ & $\begin{array}{l}0 \\
n \\
\end{array}$ & $\frac{n}{6}$ & $\begin{array}{l}8 \\
\dot{0}\end{array}$ & $\begin{array}{l}8 \\
0 \\
0\end{array}$ & $\stackrel{\Delta}{\stackrel{2}{0}}$ & $\begin{array}{l}8 \\
\text { î. }\end{array}$ & $\underset{-}{-}$ & $\underset{0}{8}$ & $\begin{array}{l}\overrightarrow{0} \\
\dot{0}\end{array}$ & \begin{tabular}{l}
8 \\
\hdashline \\
\end{tabular} & $\begin{array}{l}8 \\
\stackrel{0}{0}\end{array}$ & $\begin{array}{l}8 \\
\dot{n} \\
\ddot{\sim}\end{array}$ & 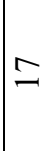 \\
\hline Z & $\cong$ & $\Re$ & $\widehat{6}$ & : & 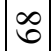 & 6 & $\cong$ & $\nabla$ & $\nabla$ & 웅 & 8 & $\stackrel{\infty}{\sim}$ & $\stackrel{R}{R}$ & 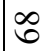 \\
\hline 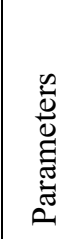 & $\frac{\pi}{2}$ & 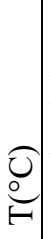 & 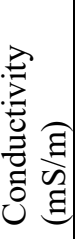 & 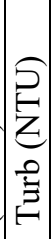 & 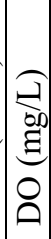 & $\left|\begin{array}{c}3 \\
0 \\
0 \\
3 \\
\vdots \\
0 \\
0 \\
0\end{array}\right|$ & 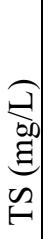 & 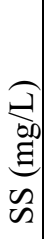 & 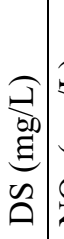 & $\begin{array}{l}\overparen{a} \\
0 \\
\Xi \\
\Xi \\
0 \\
Z \\
Z\end{array}$ & 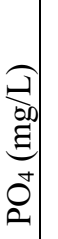 & 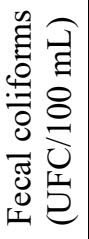 & 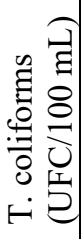 & $\bar{z}$ \\
\hline
\end{tabular}




\subsection{Data analysis}

\subsubsection{Spatial analysis}

The Kruskal-Wallis Test was applied to determine if there are significant differences for the parameters $\mathrm{pH}, \mathrm{T}\left({ }^{\circ} \mathrm{C}\right)$, conductivity $(\mathrm{mS} / \mathrm{m})$, turb $(\mathrm{NTU}), \mathrm{DO}(\mathrm{mg} / \mathrm{L}), \mathrm{BOD}_{5}(\mathrm{mg} / \mathrm{L}), \mathrm{TS}$ $(\mathrm{mg} / \mathrm{L}), \mathrm{SS}(\mathrm{mg} / \mathrm{L}), \mathrm{DS}(\mathrm{mg} / \mathrm{L}), \mathrm{NO}_{3}(\mathrm{mg} / \mathrm{L}), \mathrm{PO}_{4}(\mathrm{mg} / \mathrm{L})$, fecal coliforms (CFU/100 mL), T. coliforms (CFU/100 mL), between points JD001 (Villalobos Bathing Site), JD002 (Los Pueblos Mall and) JD003 (South Bridge Corridor), using the statistical package PAST 4.01 and SPSS Version 25.

\subsubsection{Temporal analysis}

The Mann-Whitney U Test was applied to determine if there are significant differences between the dry and wet season of the parameters $\mathrm{pH}, \mathrm{T}\left({ }^{\circ} \mathrm{C}\right)$, conductivity $(\mathrm{mS} / \mathrm{m})$, turb (NTU), DO (mg/L), BOD $5(\mathrm{mg} / \mathrm{L}), \mathrm{TS}(\mathrm{mg} / \mathrm{L}), \mathrm{SS}(\mathrm{mg} / \mathrm{L}), \mathrm{DS}(\mathrm{mg} / \mathrm{L}), \mathrm{NO}_{3}(\mathrm{mg} / \mathrm{L}), \mathrm{PO}_{4}$ $(\mathrm{mg} / \mathrm{L})$, fecal coliforms $(\mathrm{CFU} / 100 \mathrm{~mL})$, T. coliforms $(\mathrm{CFU} / 100 \mathrm{~mL})$, using the statistical package PAST 4.01 and SPSS Version 25.

\subsubsection{WQI (water quality index)}

The WQI (water quality index) was calculated, with a minimum of nine physical-chemical and biological parameters, whose qualification is categorized as highly polluted, polluted, slightly polluted, acceptable, and uncontaminated water quality [9] (Fig. 2).

\begin{tabular}{|l|l|l|}
\hline Rank & WQI & Color \\
\hline $91-100$ & Uncontaminated & \\
\hline $71-90$ & Acceptable & \\
\hline $51-70$ & Slightly polluted & \\
\hline $26-50$ & Polluted & \\
\hline $0-25$ & Highly polluted & \\
\hline
\end{tabular}

$$
I C A=\frac{\sum_{i=1}^{n} L i * W i}{\sum_{i=1}^{n} W i}
$$

Figure 2: Rank of WQI and WQI formula.

\section{RESULTS AND DISCUSSION}

\subsection{Spatial analysis}

The variations between the sites for the respective physical-chemical and biological parameters are presented in Figs 3 and 4, the Kruskal-Wallis Test.

Significant differences between points JD001, JD002 and JD003 as can be seen in Table1. The minimum values for $\mathrm{pH}, \mathrm{DO}$ are for the JD003 site and the maximum values in $\mathrm{T}\left({ }^{\circ} \mathrm{C}\right)$, turbidity, $\mathrm{BOD}_{5}, \mathrm{NO}_{3}, \mathrm{PO}_{4}$ are for the $\mathrm{JD} 003$ site, the maximum values for $\mathrm{DO}$ is the JD001 site. 

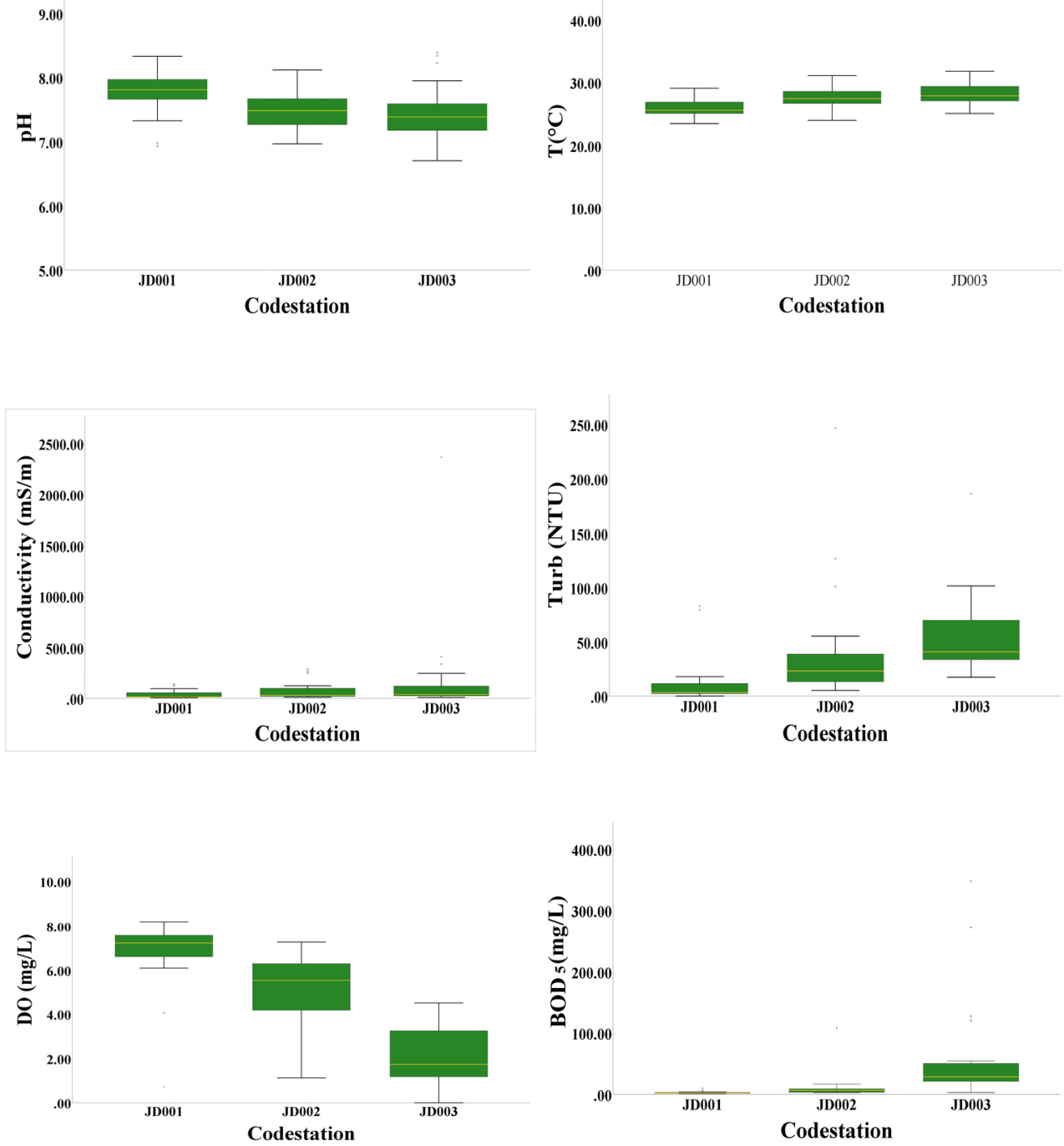

Figure 3: Boxplot of spatial variations of the selected parameters. 

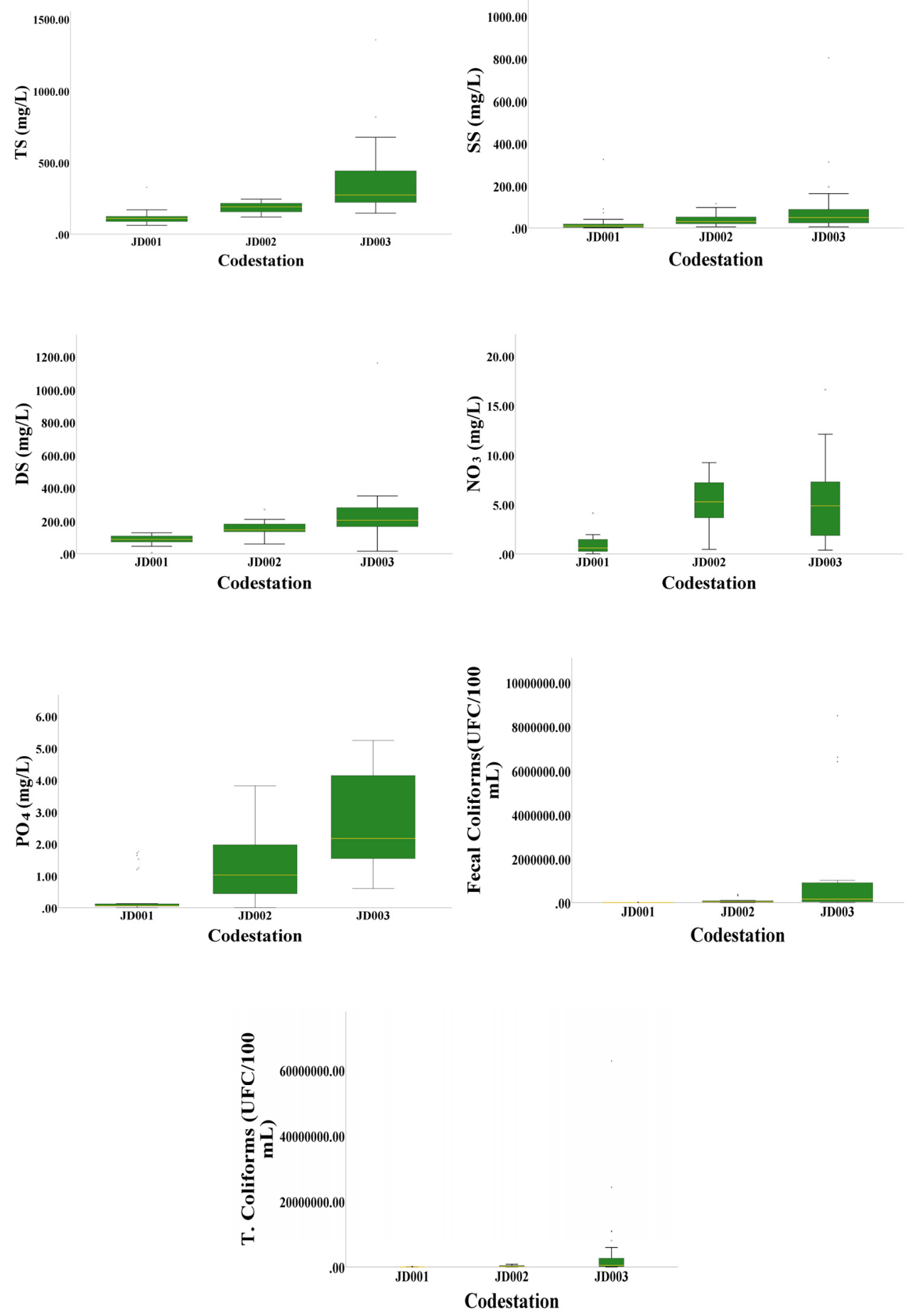

Figure 4: Boxplot of spatial variations of the selected parameters. 


\subsection{Temporal analysis}

The temporal variations for the respective physicochemical and biological parameters are presented in Figs 5 and 6, The Mann-Whitney U Test, as can be seen the results show no differences between the dry and the wet season. The parameter of $\mathrm{PO}_{4}(\mathrm{mg} / \mathrm{L})$ may indicate the presence of high intervention of industries that use or produce agrochemicals in the study area and reach the river through the rains.
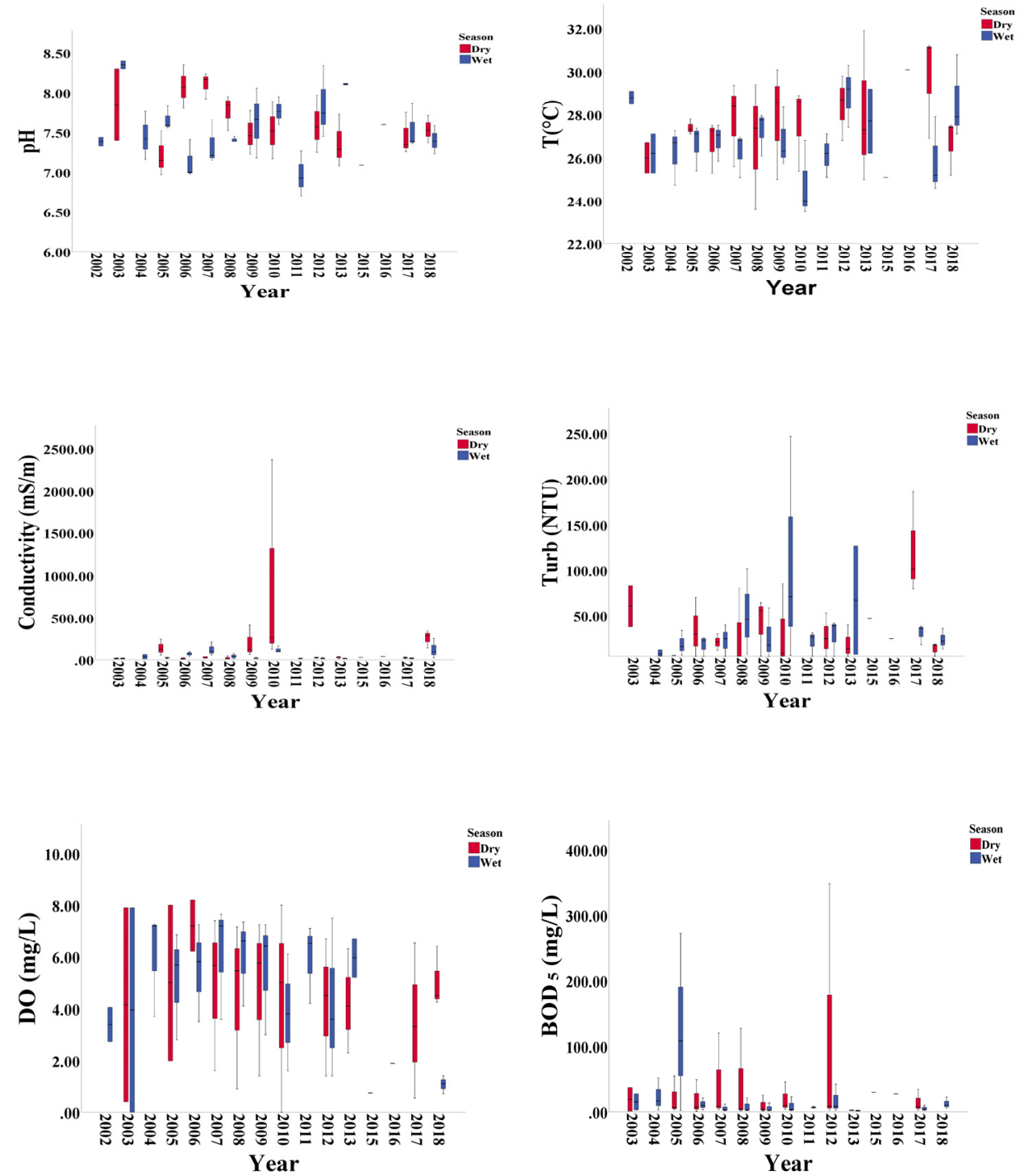

Figure 5: Boxplot of temporal variations of the selected parameters. 

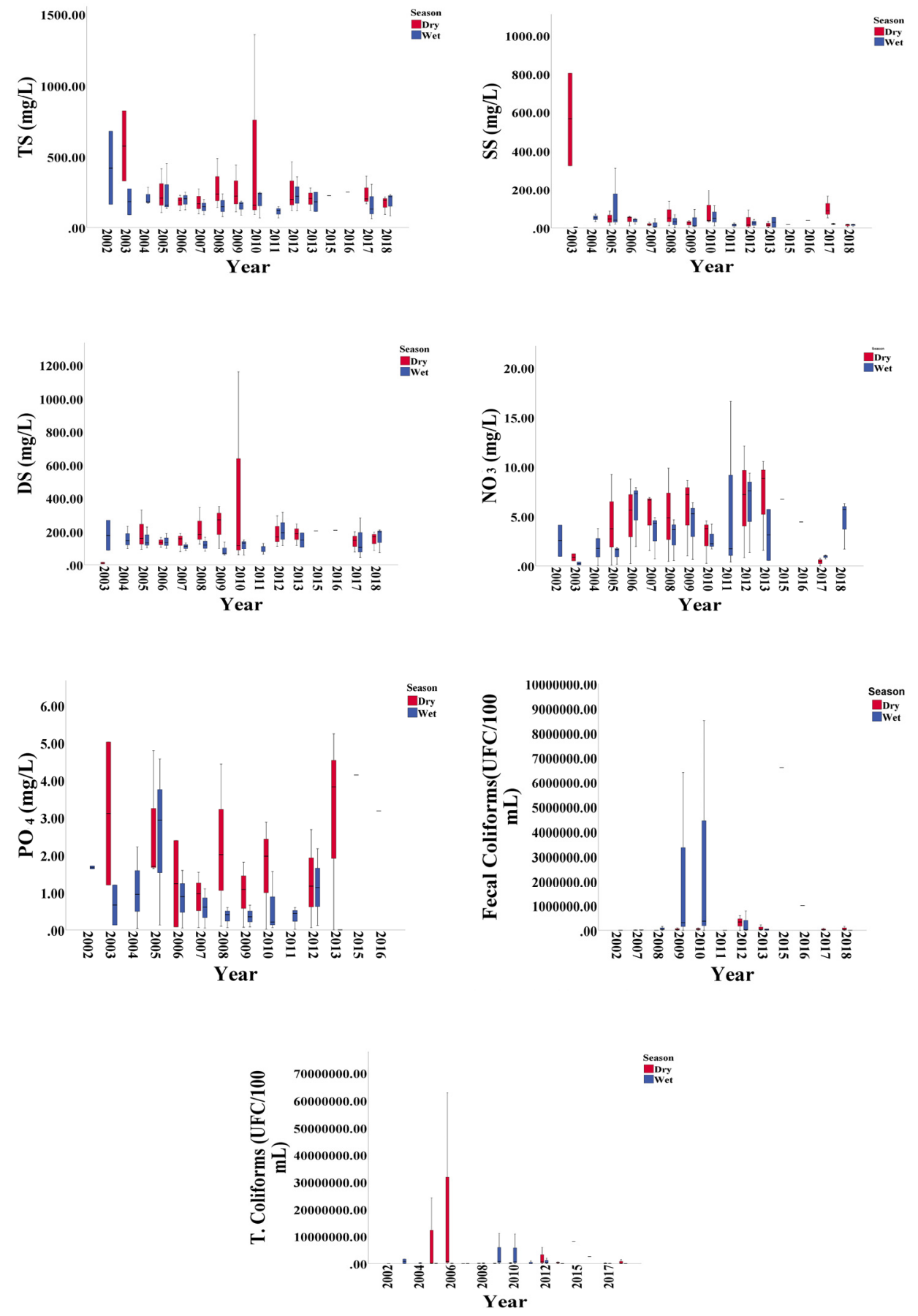

Season
Evry
Wet
Wet

Figure 6: Boxplot of temporal variations of the selected parameters. 


\subsection{WQI (water quality index)}

\subsubsection{Spatio-temporal analysis}

As can be seen in the graph for site JD001 presented WQI values between 48 and 88 that correspond to the categories of acceptable, little polluted and polluted waters, for site JD002 presented IWQ values between 25 and 68 that correspond to the categories Highly polluted, polluted and little polluted waters, for the JD003 site presented values between 17 and 53, being the category of highly polluted, polluted and little polluted waters. There are no significant differences between dry and wet season (Fig. 7).

The rivers with the greatest deterioration in the country are characterized by a high impact due to urban and industrial development, as is the case of the Juan Diaz river basin [9].
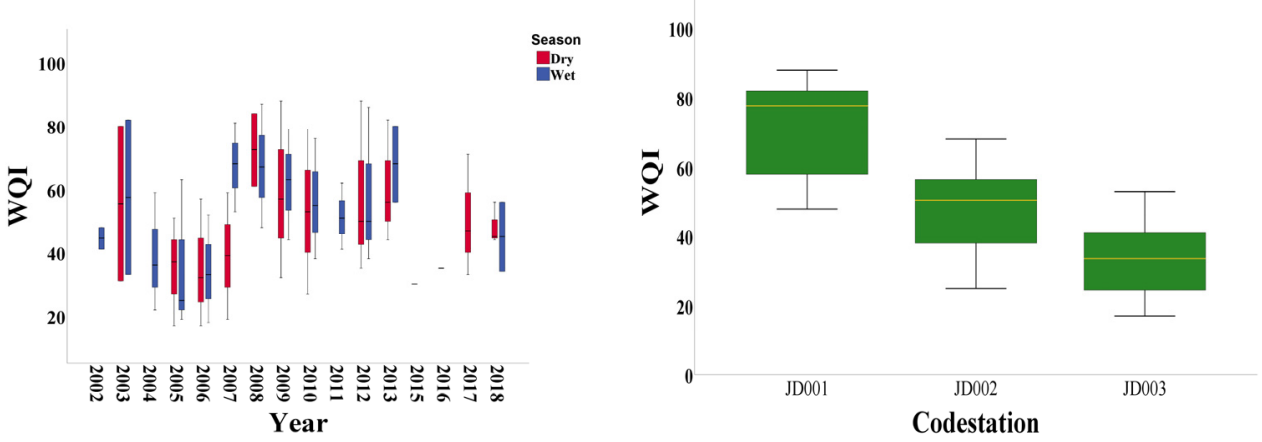

Figure 7: Boxplot of spatio-temporal variations of the selected parameters.

\section{CONCLUSION}

The results obtained in the Kruskal-Wallis Test indicate that there are significant differences between the study sites JD001 (Villalobos Bathing Site), JD002 (Los Pueblos Mall and) JD003 (South Bridge Corridor) this last point presents the higher concentration of pollutants. The Mann-Whitney U Test indicate that there are no significant differences between the dry and wet seasons except for the parameter PO4.

Analyzing the WQI values, all the stations sampled are in the range from 17 to 88 . The highest values of the index appear in the sampling station JD001 (Villalobos Bathing Site) correspond to the categories of acceptable, little polluted and polluted waters, while the sampling station JD002 (Los Pueblos Mall) that correspond to the categories highly polluted, polluted and little polluted waters and JD003 and (South Bridge Corridor) presents the lowest values with the category of highly polluted, polluted and little polluted waters. The pollution levels for the middle and lower zone of the Juan Díaz River are due to anthropogenic environmental impacts: domestic and industrial wastewater discharges and hydromorphological pressures in the river.

\section{ACKNOWLEDGEMENTS}

This research was financed by the Scholarship of the Subprogram of Doctoral and Postdoctoral Scholarships of the National Secretariat of Science and Technology (SENACYT) in conjunction with the Institute for the Training and Use of Human Resources (IFARHU). To the Ministry of the Environment of Panama that provided the data for this 
study. This research is part of the project Environmental Impact of Multiple Stressors in Aquatic Ecosystems of the Metropolitan Area of Panama, financed by SENACYT.

\section{REFERENCES}

[1] Tang, T., Cai, Q. \& Liu, J., River ecosystem health and its assessment. J. Appl. Ecol. 13(9), pp. 1191-1194, 2002.

[2] Deng, X., Xu, Y., Han, L., Yu, Z., Yang, M. \& Pan, G., Assessment of river health based on an improved entropy-based fuzzy matter-element model in the Taihu Plain, China. Ecol. Indic., 57, pp. 85-95, 2015.

[3] Sasi, S., Rayaroth, M.P., Aravindakumar, C.T. \& Aravind, U.K., Identification of surfactants and its correlation with physicochemical parameters at the confluence region of Vembanad Lake in India. Environ. Sci. Pollut. Res., 25, pp. 20527-20539, 2018. DOI: $10.1007 / \mathrm{s} 11356-017-0563-4$.

[4] Wolska, L., Sagajdakow, A., Kuczynska, A. \& Namiesnik, J., Application of ecotoxicological studies in integrated environmental monitoring: possibilities and problems. TrAC Trends Anal. Chem., 26, pp. 332-344, 2007.

[5] ANAM (National Environmental Authority), Report on the Monitoring of Water Quality in the Watersheds of Panama Compendium of Results Years 2002-2008, 2009.

[6] Bacon, C.D., Silvestro, D., Jaramillo, C., Tilston Smith, B., Chakrabartye, P. \& Antonelli, A., Biological evidence supports an early and complex emergence of the Isthmus of Panama. Proc. Natl. Acad. Sci. USA, 112(19), pp. 6110-6115, 2015.

[7] Ministry of the Environment (MiAMBIENTE), National Water Security Plan 20152050: Water for All. Panama: MiAMBIENTE/CONAGUA, 2016.

[8] APHA (American Public Health Association), Standard Methods For the Examination of Water and Wastewater, 22nd ed., American Public Health Association: Washington, DC, 2012.

[9] Cornejo, A. et al., Diagnosis of the environmental condition of the superficial tributaries of Panama, 2017. 